\title{
DEVELOPMENTAL ROLE OF PHENYLALANINE- AMMONIA-LYASE (PAL) AND CINNAMATE 4-HYDROXYLASE (C4H) GENES DURING ADVENTITIOUS ROOTING OF JUGLANS REGIA L. MICROSHOOTS
}

\author{
Monireh Cheniany* and Ali Ganjeali \\ Department of Biology, Faculty of Sciences, Ferdowsi University of Mashhad, \\ Mashhad, 91779-48974, Iran
}

(Received: February 18, 2016; accepted: April 25, 2016)

\begin{abstract}
Phenylalanine-ammonia-lyase and cinnamate-4-hydroxylase play important role in the phenylpropanoid pathway, which produces many biologically important secondary metabolites participating in normal plant development. Flavonol quercetin is the main representant of these compounds that has been identified in numerous Juglans spp. In this survey, the developmental expression patterns of PAL and C4H genes during in vitro rooting of two walnut cultivars 'Sunland' and 'Howard' was examined by RT-PCR To understand the potential role in rooting, the changing pattern of endogenous content of quercetin was also analyzed by HPLC. The 'Sunland' with better capacity to root had more quercetin content during the "inductive phase" of rooting than 'Howard'. In each cultivar, the level of $P A L$ transcripts showed the same behavior with the changing patterns of quercetin during root formation of microshoots. The positive correlation between the changes of quercetin and $P A L$-mRNA indicated that $P A L$ gene may have an immediate effect on flavonoid pathway metabolites including quercetin. Although the behavioral change of $C 4 H$ expression was similar in both cultivars during root formation (with significantly more level for 'Howard'), it was not coincide with the changes of quercerin concentrations. Our results showed that $C 4 H$ function is important for the normal development, but its transcriptional regulation does not correlate with quercetin as an efficient phenolic compound for walnut rhizogenesis.
\end{abstract}

Keywords: Phenylalanine-ammonia-lyase gene - cinnamate 4-hydroxylase gene - quercetin - in vitro culture - Juglans regia L.

\section{INTRODUCTION}

An efficient micropropagation system offers a useful alternative for rapid plant production, which is convenient for conservation and commercial production of plant species [14]. Adventitious rooting (AR) is a key process for micropropagation of these important species [1]. It originates from organs other than roots, like leaves

*Corresponding author; e-mail addresses: cheniany@um.ac.ir; monireh.cheniany@gmail.com

Abbreviations: AR: Adventitious rooting. BAP: 6-Benzylaminopurine. C4H: Cinnamate 4-hydroxylasegene. 4CL: 4-coumarate coenzyme A: ligase. DKW: Driver and Kuniyuki medium. HPLC: High performance liquid chromatography. IBA: Indol butyric acid. MS: Murashige and Skoog medium. PAL: Phenylalanine-ammonia-lyase. RBI: Relative band intensity. RT-PCR: Reverse transcription polymerase chain reaction. 
or stems [34]. AR can be divided into two main phases, each with its own specific requirements and characteristics: (1) induction, involving early biochemical and molecular events; and (2) formation, consisting in the first cellular divisions involved in root meristem organization and primordium establishment, followed by root elongation [1]. However, AR of microcuttings in micropropagation is often problematic and can be affected by multiple factors [12]. The metabolism of phenolic compounds as one of the factors controlling rhizogenesis is completely integrated into morphological and biochemical regulatory patterns of plants [45]. In Juglans regia as a hard difficult-to-root plant, naphthoquinones and flavonoids are considered as the major phenolic compounds [25, 26]. Among flavonoids, quercetin $\left(3,3^{\prime}, 4^{\prime}, 5,7\right.$-pentahydroxyflavone) as a flavolol derivatives, is of great interest due to its specific distribution patterns in this genus $[9,26]$. In previous survey, we investigated the role of endogenous content of total flavonoids, flavonols and proanthocianidins in rhizogenesis of walnut microshoots and suggested that the presence of flavonoids especially as flavonols in walnut tissues could inhibit AR process [8]. However, the role of quercetin and the mechanisms involving such phenolic compounds in rhizogenesis especially at gene level need to be studied in more details. To continue the study of their probable mechanism, phenylalanineammonia-lyase $(P A L)$ and cinnamate 4-hydroxylase $(C 4 H)$ genes were chosen for expression analysis (by reverse transcription polymerase chain reaction; RT-PCR). In vitro $P A L$ and $C 4 H$ expression study helps us to understand the molecular mechanism of root development and improving the quality of rooting ability of Juglans L.

Phenylpropanoid branch leads to some side branches to produce a large number of biologically important secondary metabolites, e.g. lignins, flavonoids, coumarins, phytolalexins, etc. [24, 44], participating in plant development, environmental interactions and defense responses [32, 37]. The core reactions of phenylpropanoid metabolism involve three enzymes, phenyalalanine ammonia-lyase (PAL; EC4.3.1.5), cinnamate 4-hydroxylase (C4H; EC1.14.13.11) and 4-coumarate coenzyme A: ligase (4CL; EC6.2.1.12) [20]. PAL is the first enzyme in the phenylpropanoid pathway that converts L-phenylalanine to trans-cinnamic acid [6]. Cinnamate 4-hydroxylase (C4H; EC1.14.13.11), a cytochrome P450-dependent monooxygenase (P450) catalyzes the 4-hydroxylation of trans-cinnamate to $p$-coumarate, the central step in the generation of Phe-derived substrates for many branches of phenylpropanoid metabolism. A second metabolic link couples $\mathrm{C} 4 \mathrm{H}$ to the membrane-localized NADPH: Cyt P450 oxidoreductase [31]. Since PAL and $\mathrm{C} 4 \mathrm{H}$ are key enzymes for the biosynthesis of phenolic compounds, there is considerable interest in the regulation of phenylpropanoid biosynthesis, both as a model for understanding flux control in a complex biosynthetic pathway and also for the identification of targets for biotechnological manipulation of product accumulation [44]. The aims of the study were: (1) to elucidate the changing patterns of quercetin content between two walnut cultivars during in vitro root development, and (2) to evaluate the developmental gene expression pattern of $P A L$ and $C 4 H$ genes as 
molecular steps controlling the production of secondary metabolites participating in adventitious rooting. The present communication is the first report on $\mathrm{C} 4 \mathrm{H}$ gene expression related to adventitious root regeneration.

\section{MATERIAL AND METHODS}

\section{Plant material}

In vitro microcutting of Persian walnut cultivars (Juglans regia L.) including 'Sunland' and 'Howard' cultured on DKW medium were used as the sample explants [13]. Culture condition and axillary proliferation was based on Vahdati et al. [47] and Cheniany et al. [8], on DKW medium supplemented with $2.1 \mathrm{~g} \mathrm{~L}^{-1}$ gellan gum (Phytagel, Sigma), $10^{-2} \mathrm{mg} \mathrm{L}^{-1} \mathrm{IBA}$, and $1 \mathrm{mg} \mathrm{L}^{-1}$ BAP with photoperiod of $16 / 8$ (light/dark) hours.

\section{In vitro adventitious rooting}

In vitro rooting cultures were maintained according to Cheniany et al. [7]. Briefly, the culture system consisted of two sequential steps: (1) induction, lasting 7 days in culture medium containing MS salts, $3.5 \mathrm{mg} \mathrm{L}^{-1}$ IBA and no cytokinins. Explants for rooting were kept on this induction medium in the dark [48]; (2) expression, lasting four weeks on a medium consisting in DKW salts $(0.25 \times$ gelled with gellan gum), mixed with coarse vermiculite $(1: 1.25 \mathrm{v} / \mathrm{v})$ and grown under a $16 / 8 \mathrm{~h}$ (light/dark) photoperiod [35]. The expression analysis of selected genes was monitored along the rooting process and in total, harvested 18 microcuttings at the end of multiplication phase (the $20^{\text {th }}$ days), the end of the root inductive phase (the $28^{\text {th }}$ day), after the root initiation (the $35^{\text {th }}$ day), and during the rooting expressive phase (the $42^{\text {nd }}, 49^{\text {th }}$ and $56^{\text {th }}$ days at every $7^{\text {th }}$ day) and then stored in deep-freezer $\left(-80^{\circ} \mathrm{C}\right)$ until further use [4]. For the morphological analysis, the rooting traits of 50 microcuttings were recorded at the end of the root expressive phase.

\section{Semi-quantitative expression analysis}

Total RNA was isolated from microcuttings using RNeasy ${ }^{\circledR}$ Plant Mini kit (Qiagen, USA) including DNAase-I treatment, according to the manufacturer's recommendations. Quality of the extracted RNAs was checked by measuring the absorbance at $260 / 280 \mathrm{~nm}$ by a spectrophotometer and RNAs with ratio of $\mathrm{OD}_{260} / \mathrm{OD}_{280}$ ranging from 1.8 to 2 were used for cDNA synthesis. The concentration $\left(\mu \mathrm{g} \mathrm{L}^{-1}\right)$ of RNA was calculated by the following formula [23]: Concentration of total $\mathrm{RNA}=\mathrm{OD}_{260} \times$ dilution ratio $\times 40 \mu \mathrm{g} \mathrm{L}-1$. 


\section{cDNA preparation and $R T-P C R$}

Preparation of first strand DNA was described by Cheniany et al. [7]. Briefly, it was synthesized using $5 \mu \mathrm{g}$ of total RNA in the presence of dNTPs Mix and 10X PCR buffer (Cinna Gen, Iran), oligo(dT) ${ }_{18}$, RiboLock ${ }^{\mathrm{TM}}$ RNase Inhibitor $(40 \mathrm{U} / \mu \mathrm{L})$ and reverse transcriptase M-MULV (200 U/ $\mu \mathrm{L}$, Fermentase) in a final volume of $20 \mu \mathrm{L}$. The reaction was incubated at $42{ }^{\circ} \mathrm{C}$ for $2 \mathrm{~h}$ after pre-incubation in $70{ }^{\circ} \mathrm{C}$ for $12 \mathrm{~min}$. The synthesized cDNA was stored at $-20^{\circ} \mathrm{C}$.

To amplify the fragments encoding $P A L, C 4 H$ and Tubulin (as the internal standard for normalization), Primer pairs: forward5'-CTYCTBCAAGGHTAYTCNGGCA-3'; reverse 5'-AGYTCDGARCARTAAGAWGCCA-3'; forward 5'-YGTSGTTNTTGATATCTTYA-3'; reverse 5'-TTRATRTTYTCTACRATRTAAA-3' and forward 5'-TGATTTCCAACTCGACCAGTGTC-3'; reverse 5'-ATACTCATCACCCTCGTCACCATC-3' (where $\mathrm{B}=\mathrm{C}, \mathrm{G}, \mathrm{T} ; \mathrm{D}=\mathrm{A}, \mathrm{G}, \mathrm{T} ; \mathrm{H}=\mathrm{A}, \mathrm{C}, \mathrm{T} ; \mathrm{N}=\mathrm{A}, \mathrm{C}$, $\mathrm{G}, \mathrm{T} ; \mathrm{R}=\mathrm{A}, \mathrm{G} ; \mathrm{S}=\mathrm{C}, \mathrm{G} ; \mathrm{W}=\mathrm{A}, \mathrm{T} ; \mathrm{Y}=\mathrm{C}, \mathrm{T}$;) for $P A L, C 4 H$ and Tubulin genes, respectively, were designed on the basis of highly conserved coding sequences freely available on the web (NCBI data bank). Amplification was performed using $0.8 \mu \mathrm{L}$ gene-specific forward and reverse primers, $1 \mu \mathrm{L}$ first-strand cDNA obtained as templates, $10 \mu \mathrm{L}$ PCR Master Kit (Cinna Gen, Iran) and $7.4 \mu \mathrm{L}$ dionized water in a final reaction volume of $20 \mu \mathrm{L}$, according to the manufacturer's instructions.

Polymerase chain reaction was carried out on a programmable thermocycler (Techne-Touch gene Gradient-FTG RAD 2D-LTD-UK) according to the following cycling conditions: pre-denaturation at $94{ }^{\circ} \mathrm{C}$ for $2 \mathrm{~min}$, followed by 35 cycles of DNA denaturing at $94^{\circ} \mathrm{C}$ for $30 \mathrm{~s}$, primer annealing of $P A L, C 4 H$ and Tubulin at $56.2{ }^{\circ} \mathrm{C}, 57.4{ }^{\circ} \mathrm{C}$ and $57^{\circ} \mathrm{C}$ for $30 \mathrm{~s}$, respectively and extension at $72{ }^{\circ} \mathrm{C}$ for $2 \mathrm{~min}$ and then a final extension at $72{ }^{\circ} \mathrm{C}$ for $10 \mathrm{~min}$. Finally, the PCR products were separated on $1 \%(\mathrm{w} / \mathrm{v})$ agarose gels and visualized by ethidium bromide staining. Relative band intensities (RBIs) were calculated using the phosphorimage software (V 1.7.6). The PCR-products were also sequenced and align by BLAST search and Bio-Edit (V 7.0.8) programs to confirm that amplified bands were truly target genes.

\section{Quercetin extraction and determination by HPLC}

\section{Sample preparation}

The samples of each phase with three replicates (in total, 18 ones) were prepared according to Fernández-Lorenzo et al. [17]. Oven-dried microcuttings of each cultivar were ground and $0.1 \mathrm{~g}$ quantities were extracted at $25^{\circ} \mathrm{C}$ with $3 \mathrm{ml}$ of HPLC grade methanol and then centrifuged at $3000 \mathrm{rpm}$ for $30 \mathrm{~min}$. The supernatants were evaporated to dryness in a speed-vac, and then the residue was redissolved in $2 \mathrm{ml} \mathrm{HPLC}$ grade methanol, which was centrifuged at $3000 \mathrm{rpm}$ for $30 \mathrm{~min}$. Each final extract was filtered with a $0.2 \mu \mathrm{m}$ cellulose acetate filter (Minisart) before injection. The standard quercetin (Sigma-Aldrich, USA) was prepared in HPLC grade methanol. 


\section{Separation condition}

Quercetin was analyzed using an HPLC (Shimadzu SIL-6A) with SPD detection (Shimadzu-SPD-6AV). A C-18 (Hamilton) reverse phase column $(4.1 \times 150 \mathrm{~mm}, 5 \mu \mathrm{m}$ particle size) was used. Between each analysis, a gradient elution was performed by gradually adding HPLC grade methanol to the $2 \%$ acetic acid in double distilled water solvent to obtain $30 \%$ methanol at $10 \mathrm{~min}, 70 \%$ at $50 \mathrm{~min}$, and $75 \%$ at $75 \mathrm{~min}$. The total run time was $30 \mathrm{~min}$, with $30 \mathrm{~min}$ of equilibration treatment $(100 \%$ methanol). The injection volume of sample was $20 \mu \mathrm{L}$, and the flow rate was $0.7 \mathrm{~mL}$ per min. The column temperature was $30^{\circ} \mathrm{C}$. Quercetin was detected at a wavelength of $280 \mathrm{~nm}$ with retention time $22.35 \mathrm{~min}$.

\section{Data analysis}

Means obtained from levels of gene expression and quercetin quantification were analyzed by ANOVA (SPSS 16 software) using Duncan's multiple range test (DMRT).

\section{RESULTS}

\section{Rooting}

Figure 1 shows the morphological view of cultivar microshoots at the inductive and expressive phases of root development. To develop efficient adventitious rooting for walnut, we have tested a new concentration of IBA in the induction medium of rhizogenesis. After seven days on modified medium containing $3.5 \mathrm{mg} \mathrm{L}^{-1}$ IBA, most segments of both cultivars emerged visible roots at the base of microcuttings that was always preceded by basal callus formation. However, the microcuttings of 'Sunland' exhibited a significantly better rooting at the end of root development process than 'Howard' (92\% vs. 51\%). In addition, 'Sunland' microshoots had thicker and bigger roots and more adventitious roots per explants in comparison to 'Howard' microshoots (Table 1).

Table 1

Rooting of microshoots of two Persian walnut cultivars induced in rooting medium ${ }^{\mathrm{a}}$

\begin{tabular}{|c|c|c|c|c|c|}
\hline Cultivar & $\begin{array}{c}\text { Total number } \\
\text { of microshoots } \\
\text { tested }\end{array}$ & Rooting $[\%]$ & $\begin{array}{c}\text { Number of roots } \\
{\left[\text { explant }{ }^{-1}\right]}\end{array}$ & Root length $[\mathrm{cm}]$ & $\begin{array}{c}\text { Root diameter } \\
{[\mathrm{mm}]}\end{array}$ \\
\hline 'Sunland' & 50 & $92 \pm 0.2$ & $3.26 \pm 0.42$ & $2.73 \pm 0.15$ & $3.25 \pm 0.17$ \\
\hline 'Howard' & 50 & $51 \pm 0.5$ & $2.11 \pm 0.2$ & $1.62 \pm 0.21$ & $3.18 \pm 0.13$ \\
\hline
\end{tabular}

aEach value is the mean \pm standard error $(\mathrm{SE})$ of total explants $(\mathrm{p}<0.05)$.

bRooting $(\%)=$ Total number of microshoots rooted/Total number of microshoots tested $\times 100$. 

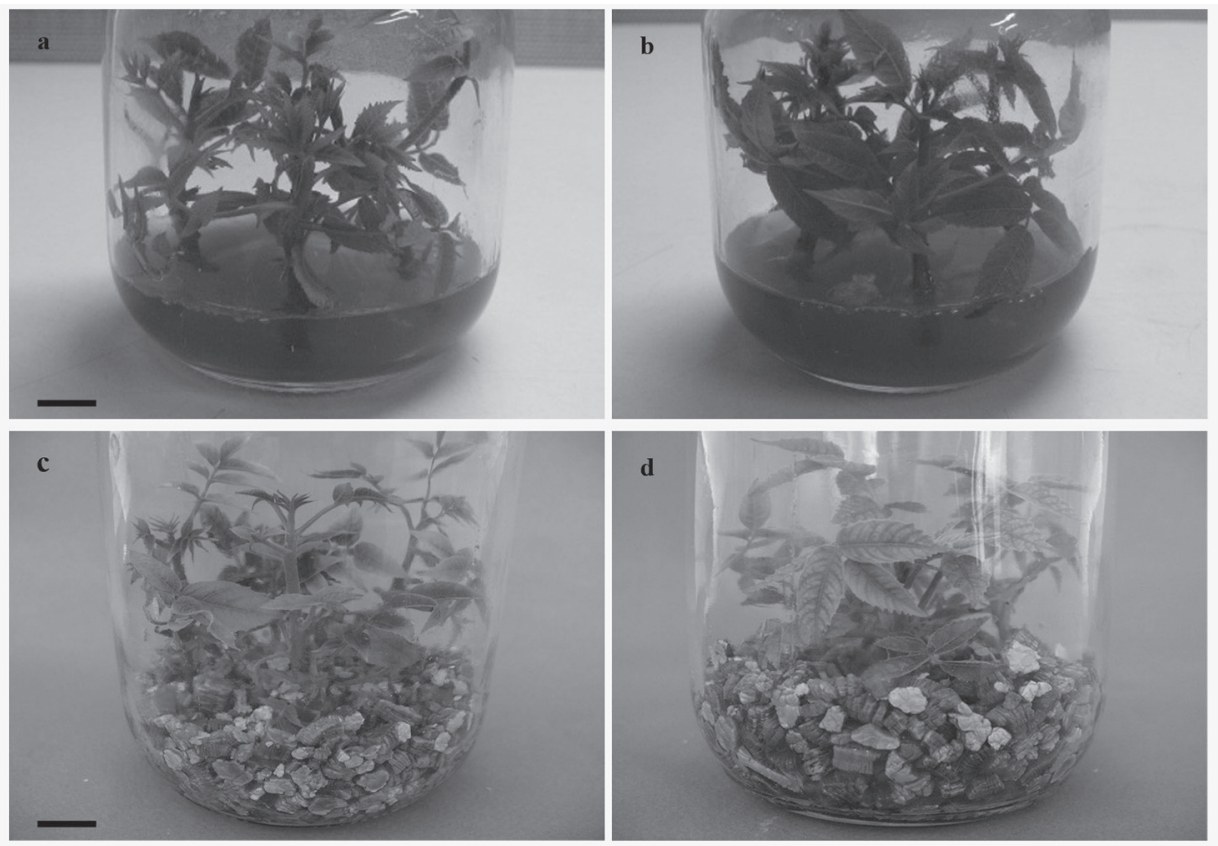

Fig. 1. Microcuttings at different phases of adventitious root development: $a$ and b 'Sunland' and 'Howard' cultivars on MS solid medium with $3.5 \mathrm{mg} \mathrm{L}^{-1}$ IBA, respectively. c and d 'Sunland' and

'Howard' cultivars on $1 / 4$ DKW medium mixed with coarse vermiculite, respectively. Scale bar $1 \mathrm{~cm}$

\section{Gene expression changes during in vitro rhizogenesis}

Considering phenolic compounds as the main secondary metabolites involved in adventitious rooting, as well as their different effects on Juglans regia L. rooting, we decided to analyze the expression patterns of genes associated with phenolic biosynthesis in microcuttings. So that, we examined the profile changes of $P A L$ and $C 4 H$ gene expression during root development by RT-PCR. The results demonstrated that $P A L$ was expressed in 'Sunland' and 'Howard' cultivars under different conditions: there was a dramatic increase (more than twofold) in the expression of $P A L$ at the end of inductive phase in 'Sunland' (Fig. 2A). Although PAL transcripts increased in 'Howard' at this time, it was not significant (Fig. 2B). In the contrary, expression of $P A L$ gene did not have any difference regarding the patterns of change during the initiative and the first weeks of expressive phases in both cultivars (Fig. 2A, B). As it is displayed in Fig. 2, the PAL mRNA accumulation was opposite in the examined cultivars at the end of expressive phase (the $56^{\text {th }}$ day), with down and up regulations for 'Sunland' and 'Howard', respectively. Gene expression analysis for $\mathrm{C} 4 \mathrm{H}$ showed that all microshoots of cultivars passing the root development had significant levels of gene transcripts. Interestingly, we found the same increasing pattern of $\mathrm{C} 4 \mathrm{H}$ expression in both walnut cultivars from the first till the end of root development 
$\oplus$
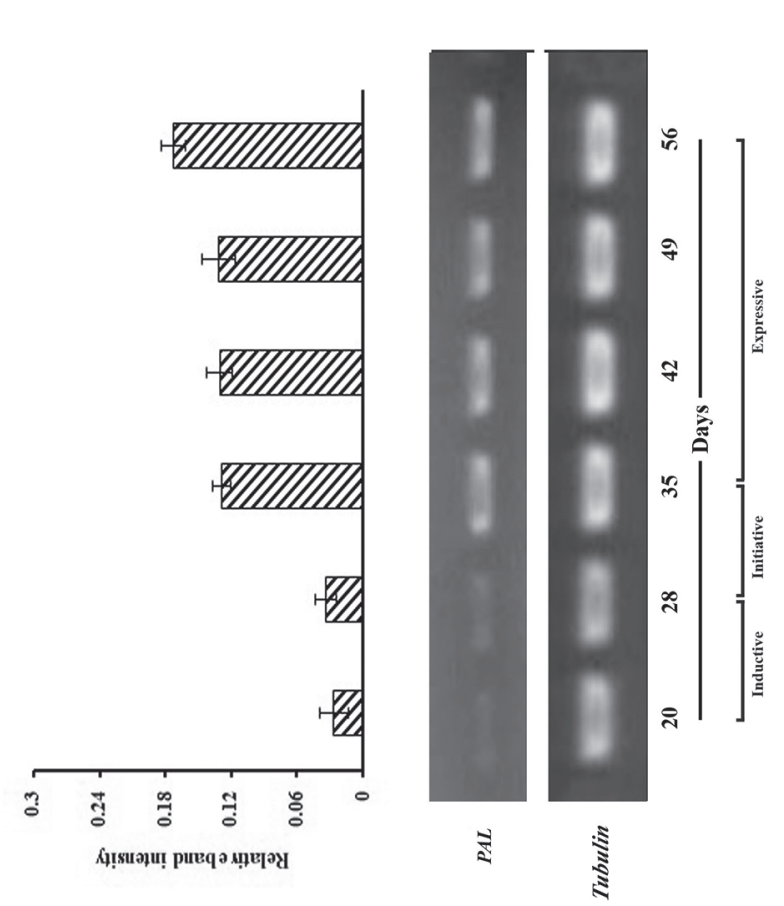

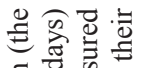

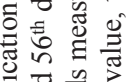

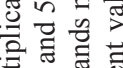

苯苧苞

苛言

政

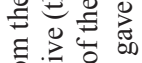

o.

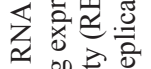

푱.

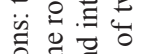

政

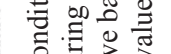

竞守 离

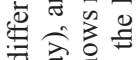

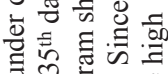

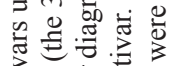

$\varangle$

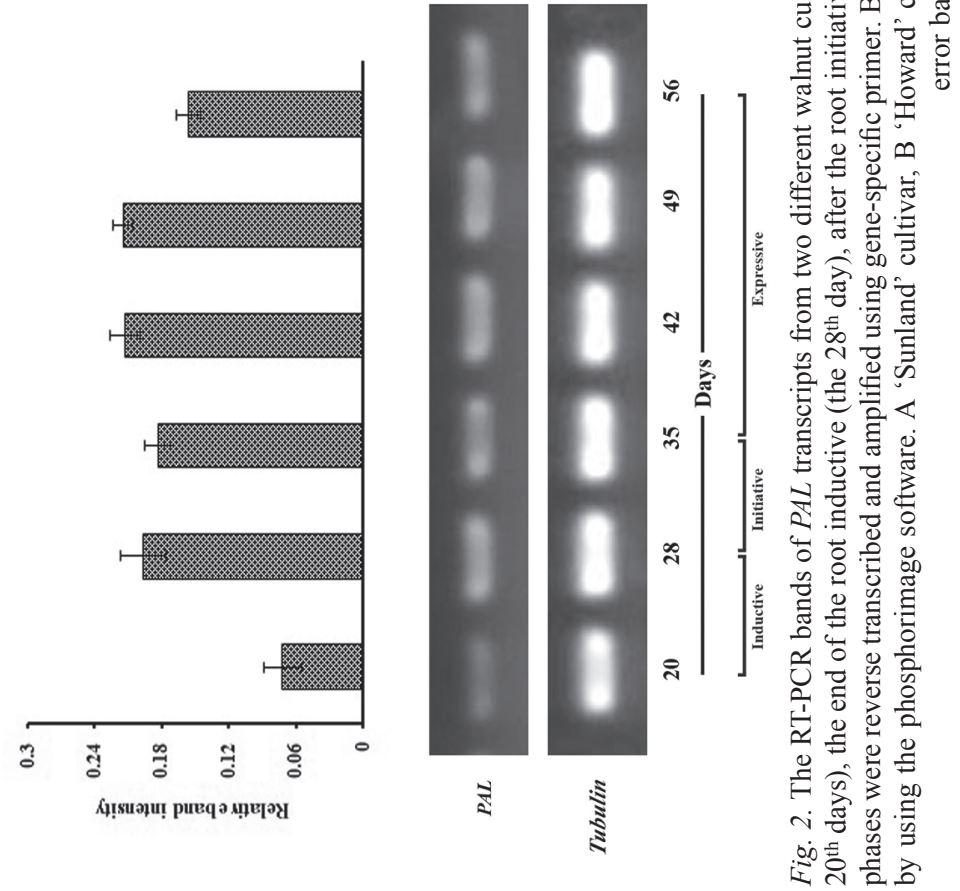

Acta Biologica Hungarica 67, 2016 
$\oplus$

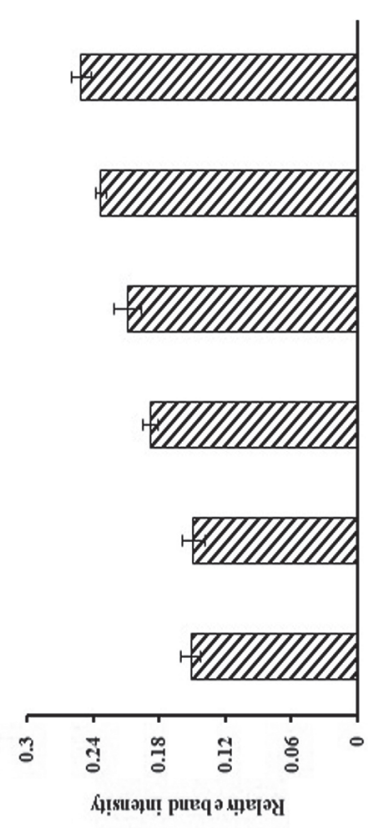

$\varangle$

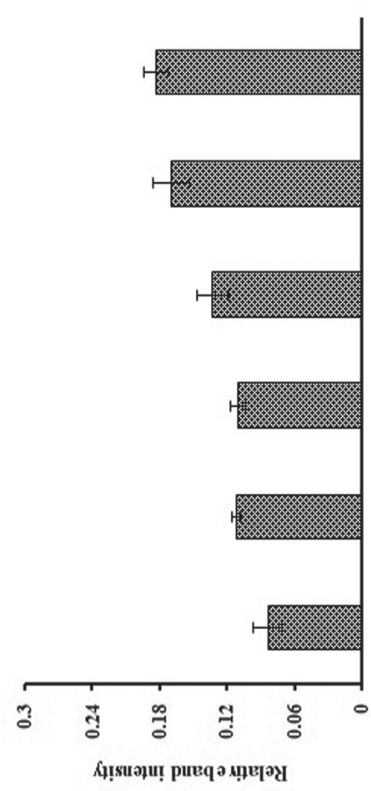

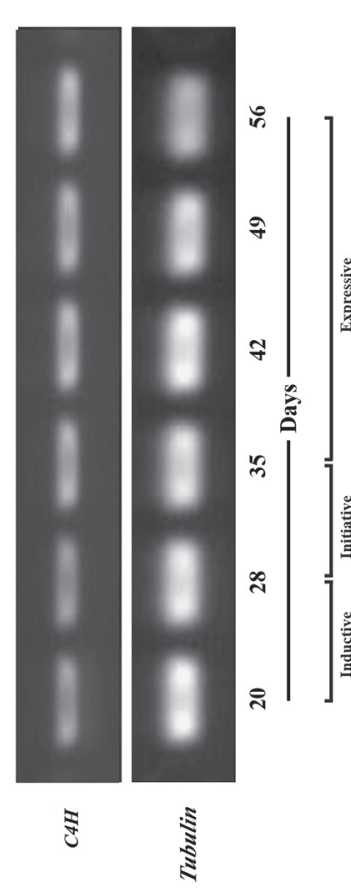

氖窟总

总

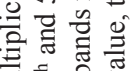

音竎总

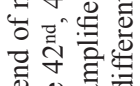

वे छ्ञ

E

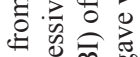

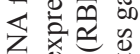

a

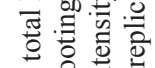

نั.

要

宅䒠 总

를

氕方高

焉专导

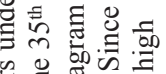

氖焉的司

主总总

ठ.

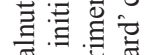

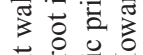

붕웜워

过

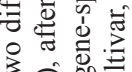

余宫

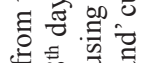

品 离

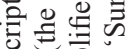

造

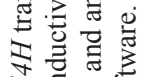

उٓ.

पे

记

눙

च्च च्रे के

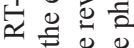

(ङ)

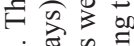

割

这竞吾各 
periods (Fig. 3A, B). However, up regulation of $\mathrm{C} 4 \mathrm{H}$ gene for 'Howard' was significantly more than 'Sunland' during rooting periods.

\section{Content changes of quercetin during in vitro root development}

Considering quercetin as the most prevalent flavonoid, we decided to analyze the changing pattern of this compound during the different phases of adventitious rooting. There were significant differences between cultivars for microshoot content of quercetin. In 'Sunland', an increase of this compound was observed from the time of application of the exogenous auxin on day 20 (after the multiplication phase) followed by a decrease till the end of initiative phase. The second increase was seen at the beginning of the expressive phase that finally continued with another elevation. The concentration of quercetin of 'Howard' decreased from the first to $28^{\text {th }}$ sampling day, and then increased through the following days by a sharp increase during the later stages of rooting (Fig. 4). Correlation coefficient analysis suggested a positive relationship between the quercetin concentration and RBI of $P A L$ expression during root development (0.845). In contrary, there was less positive correlation between the content of quercetin and RBI of $\mathrm{C} 4 \mathrm{H}$ gene (0.198).

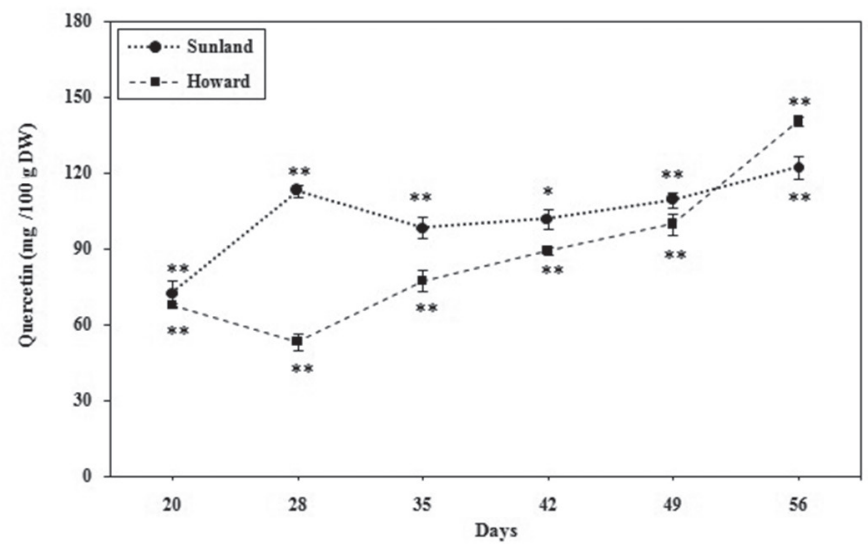

Fig. 4. HPLC analysis of quercetin content (mg $\left.100 \mathrm{~g}^{-1} \mathrm{DW}\right)$ in whole microshoots of two cultivars of Juglans regia L. sampled at different times during AR development period. Each value is the mean $( \pm \mathrm{SE})$ of three replicates. *Statistically significant differences at P-value below $0.05 .{ }^{* *}$ Statistically significant differences at P-value below 0.01

\section{DISCUSSION}

In our previous research, we showed that though Juglans regia L. is one of the more difficult-to-root plants [41], their genotypes can vary in the rooting ability under $3 \mathrm{mg}$ $\mathrm{L}^{-1}$ IBA in induction medium [7, 8]. In present study a test with $3.5 \mathrm{mg} \mathrm{L}^{-1}$ IBA were carried out in induction medium, microshoots of each cultivar showed better root 
capacity than before. It has been reported that the rhizogenic capacity of walnut depends on the endogenous content of auxin and the exogenous concentration to be used $[16,41,42]$. The results suggest that higher level of exogenous auxin up to saturation point may exert sufficient induction for in vitro root proliferation [17]. These data suggest that the cells at the base of microcuttings may produce more root apical meristems, depending on the added hormone concentrations during the inductive phase of AR [2,30]. However, with the increase of applied IBA concentration, the length of roots decreased while the diameter of them increased. That is consistent with the higher content of exogenous IBA, being more effective in promoting root diameter and its percentage [18].

Flavonoids as a major class of phenolic secondary metabolites have many physiological roles, including serving as functional constituents of biochemical systems, pigmentation or defensive compounds [10]. Quercetin is one of the more interesting flavonoid compounds. It occurs in fresh walnut leaves, shoots and roots [9]. In this experiment, a significant difference was observed in the changing pattern of quercetin content between examined cultivars during the induction phase of AR. The 'Sunland' with better capacity to root had more quercetin content during the inductive phase of rooting than 'Howard'. Our finding is consistent with those of Jay-Allemand et al. [26] who reported that the promoting role of quercitrin (a glycone form of quercetin) during the root induction of Juglan regia microcuttings. Curir et al. [11] also suggested that quercetin derivatives in the living tissue of Eucalypts gunnii, take part in developmental processes of microcutting rooting. Encouraging affect of quercetin on the formation of adventitious roots of Ilex paraguariensis cuttings was stated by Tarrago et al. [46]. Because the induction of adventitious rhizogenesis is an important aspect of this process [7], it can be concluded that quercetin has a positive effect on this phase of rooting and can be considered as one of endogenous effectors of root development.

The phenolic compounds have their origin in the general phenylpropanoid metabolism catalyzing by $P A L$ and $C 4 H$ at two early steps. The $P A L$ gene encodes phenylalanine-ammonia-lyase, the first committed enzyme that its activity varies with the development stage of the plant and cell and tissue differentiation [38]. We have analyzed the level of $P A L$ expression during in vitro rooting to know whether changes in the levels of quercetin content contribute to the transcriptional control of $P A L$ gene. In each cultivar, the level of $P A L$ transcripts showed the same behavior with patterns of change in quercetin compound. It can therefore be concluded that the control of flavonoid metabolism, at least in part, is at the level of transcription of some genes encoding biosynthetic enzymes. The present study suggests that $P A L$ gene is one of those genes. Several studies have confirmed that the high expression of $P A L$ of different tissues correlates with the biosynthesis and accumulation of high levels of phenolic compounds $[15,27,29,39]$. PAL expression in examined cultivars during the induction phase of AR showed that 'Sunland' with better capacity to root and more level of endogenous quercetin had higher levels of PAL mRNA than 'Howard'. These 
results indicated that $P A L$ gene with developmentally regulated expression $[21,22$, 33], has an immediate effect on metabolic flux into phenylpropanoid pathways [19].

The data of this survey show the same patterns of change for $C 4 H$ transcripts in both cultivars with significantly more one for 'Howard'. Accordingly, $\mathrm{C} 4 \mathrm{H}$ expression was not coordinated with $P A L$ expression under microshoots in vitro rooting. This not significant coordination of these two genes has also been reported by Pina and Errea under graft experiments [40]. It has been reported $C 4 H$ that genes could exist as a multi gene family in various plant species and the divergent isoforms could play distinct roles in the biosynthesis of extremely diverse primary and secondary metabolites such as fatty acids, phenylpropanoids, alkaloids, and terpenoids [5, 37]. As a matter of fact, it is likely that these proteins and the factors that regulate the expression of their corresponding genes are divergent and this causes their critical roles in the biochemistry and development of plants [3]. It confirms our earlier results showing that although $C 4 H$ function is important for the normal development [28, 37, 43]; its transcriptional induction does not apparently correlate with analyzed useful phenolic compound, quercetin. The results obtained from in vitro studies demonstrated that developmentally regulated $\mathrm{C} 4 \mathrm{H}$ expression may be correlated with lignifications and other sites of active metabolism [31,36]. Its regulation in a temporal and spatial manner consistent in lignification has been confirmed [49]. However, further studies on the function and regulation of $\mathrm{C} 4 \mathrm{H}$ are required to elucidate its specific roles in rhizogenesis. In conclusion, based on a positive correlation between expression of $P A L$ gene and quercetin content, it is suggested that the regulation of flavonol concentrations is, at least in part, under $P A L$ transcriptional regulation and PAL enzyme has critical role in quercetin biosynthesis and a cross talk between shikimate and phenylpropanoid pathways.

\section{ACKNOWLEDGEMENT}

This work was financially supported by Ferdowsi University of Mashhad, Iran (grant Nos. 2/29648).

\section{REFERENCES}

1. Almeida, M. R. D., Bastiani, D. D., Gaeta, M. L., Mariath, J. E. D. A., Costan F. D., Retallick, J., Nolan, L, Tai, H. H., Stromvik, M. V., Fett-Neto, A. G. (2015) Comparative transcriptional analysis provides new insights into the molecular basis of adventitious rooting recalcitrance to Eucalyptus. Plant Sci. 239, 155-165.

2. Aremu, A. O., Bairu, M. W., Szüčová, L., Doležal, K., Finnie, J. F., Staden, J. V. (2012) Shoot and root proliferation in "Williams" banana: are the topolins better cytokinins? Plant Cell Tiss. Organ Cult. 111, 209-218.

3. Bell-Lelong, D. A., Cusumano, J. C., Meyer, K., Chapple, C. (1997) Cinnamate 4-hydroxylase expression in Arabidopsis. Plant Physiol. 113, 729-738.

4. Bisbis, B., Kevers, C., Crovecoeur, M., Dommes, J., Gaspar, T. (2003) Restart of lignifications in micropropagated walnut shoots coincides with rooting induction. Biologia Plant. 47, 1-5.

5. Chapple, C. (1998) Molecular-genetic analysis of plant cytochrome P45o-dependent monooxygenases. Annu. Rev. Plant Physiol. Plant Mol. Biol. 49, 311-343. 
6. Chen, A., Li, J., Chai, Y., Wang, R., Lu, J. (2008) Cloning and sequence analysis of a mutation-type cinnamate 4-hydroxylase gene from Brassica oleracea L. var. acephala DC. Front Agric China 2, 456-462.

7. Cheniany, M., Ebrahimzadeh, H., Masoudi-nejd, A. (2012) Expression of chalcone synthase influences flavonoid content and frequency of rhizogenesis in microshoots of Juglans regia L. Plant Cell Tiss. Organ Cult. 109, 51-59.

8. Cheniany, M., Ebrahimzadeh, H., Masoudi-nejd, A., Vahdati, K., Leslie, Ch. (2010) Effect of endogenous phenols and some antioxidant enzyme activities on rooting of Persian walnut (Juglans regia L.). Afr. J. Plant Sci. 4, 479-487.

9. Cheniany, M., Ebrahimzadeh, H., Vahdati, K., Preece, J. E., Masoudi-nejd, A., Mirmasoumi, M. (2013) Content of different groups of phenolic compounds in microshoots of Juglans regia cultivars and studies on antioxidant activity. Acta Physiol. Plant. 35, 443-450.

10. Cohen, M. F., Sakihama, Y., Yamasaki, H. (2001) Roles of plant flavonoids in interactions with microbes: from protection against pathogens to the mediation of mutualism. Recent Res. Devel. Plant Physiol. 2, 157-173.

11. Curir, P., Van Sumere, C. F., Termini, A., Barthe, P., Marchesini, A., Dolci, M. (1990) Flavonoid accumulation is correlated with adventitious roots formation in Eucalyptus gunnii Hook micropropagated through axillary bud stimulation. Plant Physiol. 92, 1148-1153.

12. Davis, T. D., Haissig, B. E. (1994) A historical evaluation of adventitious rooting research to 1993. In: Davis, T. D., Haissig, B. E. (eds) Biology of Adventitious Root Formation. Basic Life Sciences. vol 62. Plenum Press. New York. pp. 274-335.

13. Driver, J. A., Kuniyuki, A. H. (1984) In vitro propagation of Paradox walnut rootstock. Hort Sci. 19, 507-509.

14. Elias, H., Taha, R. M., Hasbullah, N. A., Mohamad, N., Manan, A. A., Mahmad, N., Mohajer, S. (2014) The effects of plant growth regulators on shoot formation regeneration and colored callus production in Echinocereus cinerascens in vitro. Plant Cell Tiss. Organ Cult. DOI 10.1007/s11240014-0642-x.

15. English, S., Greenaway, W., Whatley, F. R. (1991) Analysis of phenolics of Populus trichocarpa by GC-MS. Phytochem. 30, 531-533.

16. Feito, I., Gea, M. A., Ríos, D., Albuerne, M., Fernández, B., Rodríguez, R. (1997) Physiological studies during walnut rooting. Acta Hort. 442, 137-142.

17. Fernández-Lorenzo, J. L., Ballester, A., Rigueiro, A. (2005) Phenolic content of microcuttings of adult chestnut along rooting induction. Plant Cell Tiss. Organ Cult. 83, 153-159.

18. Fernández, H., Pérez, C., Sánchez-Tamés, R. (2000) Modulation of the morphogenic potential of the embryonic axis of Juglans regia by cultural conditions. Plant Growth Reg. 30, 125-131.

19. Gray-Mitsumune, M., Molitor, E. K., Cukovic, D., Carlson, J. E., Douglas, C. J. (1999) Developmentally regulated patterns of expression directed by poplar PAL promoters in transgenic tobacco and poplar. Plant Mol. Biol. 39, 657-669.

20. Hahlbrock, K., Scheel, D. (1989) Physiology and molecular biology of phenylpropanoid metabolism. Annu. Rev. Plant Physiol. Plant Mol. Biol. 40, 347-369.

21. Hatton, D., Sablowski, R., Yung, M. H., Smith, C., Schuch, W., Bevan, M. (1995) Two classes of cis sequences contribute to tissue-specific expression of a PAL2 promoter in transgenic tobacco. Plant J. 7, 859-876.

22. Hatton, D., Smith, C., Bevan, M. (1996) Tissue-specific expression of the PAL3 promoter requires the interaction of two conserved cis sequences. Plant Mol. Biol. 31, 393-397.

23. He, F., Wang, H., Song, X., Zhang, Zh. (2011) Comparison of the methods of RNA isolation from Juglans regia L. buds. Front Agric China 5, 221-224.

24. Huang, B., Duan, Y., Yi, B., Sun, L., Lu, L., Yu, X., Sun, H., Zhang, H., Chen, W. (2008) Characterization and expression profiling of cinnamate 4-hydroxylase gene from Salvia miltiorrhiza in rosmarinic acid biosynthesis pathway. Russian J. Plant Physiol. 55, 390-399. 
25. Jay-Allemand, C., Charpentier, J. P., Bruant, B., Burtin, P., Fady, B., Lefevre, F. (2001) Genetic of phenolic compounds in walnut: qualitative and quantitative variations among cultivars. Acta Hort. $544,73-81$.

26. Jay-Allemand, C., Peng, S., Capelli, P., Cornu, D. (1993) Micropropagation of hybrid walnut trees: some factors involved in rooting. Acta Hortic. 311, 117-124.

27. Kao, Y. Y., Harding, S. A., Tsai, C. J. (2002) Differential expression of two distinct phenylalanine ammonia-lyase genes in condensed tannin-accumulating and lignifying cells of quaking aspen. Plant Physiol. 130, 796-807.

28. Kim, J., Choi, B., Natarajan, S., Bae, H. (2013) Expression analysis of kenaf cinnamate 4-hydroxylase $(\mathrm{C} 4 \mathrm{H})$ ortholog during developmental and stress responses. Plant Omics J. 6, 65-72.

29. Kiselev, K. V., Dubrovina, A. S., Bulgakov, V. P. (2009) Phenylalanine ammonia-lyase and stilbene synthase gene expression in rolB transgenic cell cultures of Vitis amurensis. Appl. microbial. biotechnol. 82, 647-655.

30. Klerk, G. J. D. (2002) Rooting of microcuttings: theory and practice. In Vitro Cell Dev. Biol. Plant. $38,415-422$

31. Koopmann, E., Logemann, E., Hahlbrock, K. (1999) Regulation and functional expression of cinnamate 4-hydroxylase from parsley. Plant physiol. 119, 49-56.

32. Lee, Y. J., Jeon, Y., Lee, J. S, Kim, B. G., Lee, Ch. H., Ahn, J. H. (2007) Enzymatic synthesis of phenolic CoAs using 4-coumarate:coenzyme A ligase (4CL) from rice. Bull. Korean Chem. Soc. 28, 365-366.

33. Leyva, A., Liang, X., Pintor-Toro, J. A., Dixon, R. A., Lamb, C. J. (1992) Cis-element combinations determine phenylalanine ammonia-lyase gene tissue-specific expression patterns. Plant Cell. 4 261-271.

34. Li, S. W., Xue, L., Xu, S., Feng, H., An, L. (2009) Mediators, genes and signaling in adventitious rooting. Bot. Rev. 75, 230-247.

35. Liu, Ch., Callow, P., Rowland, L. J., Hancock, J. F., Song, G. (2010) Adventitious shoot regeneration from leaf explants of southern highbush blueberry cultivars. Plant Cell Tiss. Organ Cult. 103, $137-$ 144

36. Liu, Sh., Hu, Y., Wang, X., Han, L., Song, S., Cheng, H., Lin, Zh. (2009) Isolation and characterization of a gene encoding cinnamate 4-hydroxylase from Parthenocissus henryana. Mol. Biol. Rep. 36, $1605-1610$.

37. Lu, Sh., Zhou, Y., Li, L., Chiang, V. L. (2006) Distinct roles of cinnamate 4-hydroxylase genes in Populus. Plant Cell Physiol. 47, 905-914.

38. Morelló, J. R., Romero, M. P., Ramo, T., Motilva, M. J. (2005) Evaluation of L-phenylalanine ammonia-lyase activity and phenolic profile in olive drup (Olea europaea L.) from fruit setting period to harvesting time. Plant Sci. 168, 65-72.

39. Pellegrini, L., Rohfritsch, O., Fritig, B., Legrand, M. (1994) Phenylalanine ammonia-lyase in tobacco. Molecular cloning and gene expression during the hypersensitive reaction to tobacco mosaic virus and the response to a fungal elicitor. Plant Physiol. 106, 877-886.

40. Pina, A., Errea, P. (2008) Differential induction of phenylalanine ammonia-lyase gene expression in response to in vitro callus unions of Prunus spp. J. Plant Physiol. 165, 705-714.

41. Ríos, D. G., Sánchez-Olate, M., Gea, M. A., Revilla, M. A., Rodríguez, R. (1997) Rooting responses in relation with PO, PPO and IAA-o activities on walnut (Juglans regia L.) explants. Acta Hort. 442, $241-250$.

42. Ríos, D. G., Sánchez-Olate, M., Gea, M. A., Rodríguez, R. (2002) Nuevos sistemas Experimentales para el studio de la rizogénesis en nogal. Agrociencia 17, 221-227.

43. Schilmiller, A. L., Stout, J., Weng, J. K., Humphreys, J., Ruegger, M. O., Chapple, C. (2009) Mutations in the cinnamate 4-hydroxylase gene impact metabolism, growth and development in Arabidopsis. Plant J. 60, 771-782.

44. Singh, K., Kumar, S., Rani, A., Gulati, A., Ahuja, P. S. (2009) Phenylalanine ammonia-lyase (PAL) and cinnamate-4-hydroxylase $(\mathrm{C} 4 \mathrm{H})$ and catechins (flavan-3-ols) accumulation in tea. Funct Integr Genomics 9, 125-134. 
45. Solar, A., Colaric, M., Usenik, V., Stampar, F. (2006) Seasonal variations of selected flavonoids, phenolic acids and quinines in annual shoots of common walnut (Juglans regia L.). Plant Sci. 170, 453-461.

46. Tarrago, J., Sansberro, P., Filip, R., Lopez, P., Gonzalez, A., Luna, C., Mroginski, L. (2005) Effect of leaf retention and flavonoids on rooting of Ilex paraguariensis cuttings. Scientia Hort. 103, 479-488.

47. Vahdati, K., Leslie, C., Zamani, Z., Mcgranahan, G. (2004) Rooting and acclimatization of in-vitro grown shoots from three mature Persian walnut cultivars. Hort Sci. 39, 324-327.

48. Vahdati, K., Martinez-Gomez, P., Leslie, C., Mcgranahan, G. (2001) Rooting ability of walnut cultivars and peroxidase analysis. Hort Sci. 36, 458-464.

49. Ye, A. H. (1996) Expression of the cinnamic acid 4-hydroxylase gene during lignifications in Zinnia elegans. Plant Sci. 121, 133-141. 